\title{
Modality-Resurgence of Musical Thinking
}

\author{
Jozef Veres \\ Department of Music \\ Constantine the Philosopher University in Nitra, Slovakia
}

\begin{abstract}
Paper focuses on the examination and interpretation of certain modal technologies in $20^{\text {th }}$ century music creation. Author draws attention to new ways of musical-modal material selection within musical- theoretical interpretation of the modalities, as well as utilization of such material in music creation from the decomposition of tonal harmony. Special attention is devoted to the music culture in Central Europe. Paper significantly presents the most characteristic signs of modal forms applied in music of Béla Bartók and Eugen Suchoň through analysis and comparison. Complex study offers educational initiatives providing more clearly educational production of E. Suchoň.
\end{abstract}

\section{Keywords:}

tonal harmony, modality, music culture, music of spontaneous creativity, folk song, religious modes.

\section{INTRODUCTION}

Over 19th century there were significant processed on the go in the European music culture which resulted into degradation of tonal harmony, tonal system as well as renewal of music language. This process is characterized by the introduction of greater freedom in the music composition as opposite to artifacts composed in the tonal system. New ways of tone changing from modes material is registered, new intervals in the chord structures are applied, New Harmony relations are present. We notice increase of non-tonal and altered chord adding (Wagner), departure from the principles of functional harmony and opening the way to connecting chords without fifth-relatedness (Debussy).

Development in the music composition did not consist only of modified application of the ancient music modes ${ }^{1}$, but also out of impulses arisen from folk and non-European music, by elaboration of own modes as well as ways of tone organizing within the modes creating methods to support modality resurgence, its new turnovers on a new higher level. Modal technologies were applied mainly in compositions of The Second Viennese School (A. Schőnberg, A. Berg, A. Webern), Russian The Mighty Handful (M. Balakijev, A. Borodin, C. Kjui, M. Musorskij, N. Rimskij-Kosakov), French impressionists, national schools etc. Their compositions supported rational technologies to bloom mainly hacked by dodecaphonic way of composing when considering composing practice. Such composition technique had freer tone movements, chord relations changed by more stringent rules in comparison with classical tonal functional system. At this point it should also be noted that the mentioned practices of music composition were characteristic more-less for the European music of the $20^{\text {th }}$ century and its developmental phases. In spite of the fact, our reflections lead us to form the following thoughts: those are attributes of the $20^{\text {th }}$ century music only, or even timeless principles, due to

\footnotetext{
1 Mode as musical term means size of tone movement, melody. Originally referred to rule, time measurement, and
} sound expressions. Modality points to structural characteristics in music pieces, based on mode utilization. 
their appearance in older music creations (for example, in Medieval and Renaissance music, in various ethnic musical expressions, and so on). The above statement can be extended to uncovering the connection between tonal and freely tonal music. This connections was mainly used by Slovak composer, theorist, teacher Eugen Suchoň (1908-1993), composer of Slovak National Opera „Krútňava." 2

\section{MODALITY AND ITS CONTEXTS}

We encounter term "modality" $\mathrm{n}$ various contexts as a part of the development of music, the development of musical thoughts. Old Sacral scales ${ }^{3}$ at times of J. Rameau (1683-1764) got somehow into "omission" because musical thinking was swinging within the context of major minor. If some composers used old modes in their compositions, such as F. Liszt (1811-1886) or R. Wagner (1813-1883), herein procedure was interpreted often as "exotic spice" of chromatics. The presence of the term modality on $20^{\text {th }}$ century is more evident from the times of O. Messiaen (1908-1992). Pioneering position, however, has been associated with the masterpieces of B. Bartók (1881-1945) connected to folk music and recognition of C. Debussy's music (1862-1918), ${ }^{4}$ which may be denoted as a decisive turning point in his style orientation.

Modality was typically initially looked for in melodics, in folklore, which tone scales had similarities with sacral scales. Later, modality was considered in connection to compositional utilization of folk music incentives. Non-European tonalities, such as pentatonic, were included in the concept of modality, which gradually enforced effort musical creators and theorists to clarify principles of so called modal harmony. It is also known that certain theoretical schools did not always use the term modality. For example Rudolf Reti ${ }^{5}$ considered B. Bartók, L. Janáček (1854-1928) as pioneers of pantonality ${ }^{6}$ (however, the term did not acquire the necessary bearing). In Slovakia but also in Poland old folk songs included modal scales (c-d-e-f sharp-g-a-b-c) often referred to as podhalanská, ${ }^{7}$ it binds in Wallachia and Goral culture. Jerzy Mlodziejowski called one period of production of K. Szymanowski also „podhalanským..“8

In the current musical theories term modus more or less does not apply only to the sacral tonality, since it becomes a base, core for the construction of melody and harmony. It is up to the composer which mode and system of chord structure will be chosen for his music thinking. Groundbreaking phase in the development of music is most often been associated with piecesof C. Debussy (1862-1918). Among its attributes especially upheaval of sound quality of

\footnotetext{
2 MARTINÁKOVÁ Zuzana. Úvahy o možnostiach organizácie tónov na pozadí Suchoňovho systému akordiky. In Slovenská hudba, roč. 24, č. 1-2, 1998. s. 36- 46. [Reflections on tonal organization options based on Eugen Suchoň's chord-system]. Similar resolution is found also in VEREŠ, Jozef and MAJERNÍK, Vladimír in paper Hudobná teória. 1980. [Music Theory] (Zodp. red. Zorka Nünzová). Bratislava: SPN, 1980, 144 s.

3 Other terms are also used, i.e. medieval tone scales (modes), which had its characteristics and indications, for example, Dorian, Phrygian etc. From the earlier period Classical Greek tone scales are known that were read from top to bottom.

${ }^{4}$ In his initial stages he related to late romantic tradition (F.Liszt, R.Strauss).

${ }^{5}$ Rudolf Reti was born on 27. 11. 1885 in Serbia. Died in 1957. He studied in Vienna Music science, piano. He was also taught by A. Schőnberg.

${ }^{6}$ One of the features is the free use of dissonance, that at Reti represent fictive cancellation of contrast tonality atonality.

${ }^{7}$ Because of its structure is also referred to as Lydian - Mixolydian (c-f sharp; c-b).

8 Podhalanská is the border area between Poland and Slovakia. Following pieces are included into herein period: Harnasie- Ballet - premiered in Prague in 1935 in directing of Munclingr, Mazurkas, Second Violin Concerto, Second String Quartet, Fourth symphony with a piano.
} 
a single tone or tone combinations are dominant as factors forming structure of musical piece, based on the platform equivalence with melodies and harmonies (from the times of Debussy focus laid on concords, not chords that much). Although mentioned composer had balanced certain time between harmonic and modal thinking, he contributed significantly to the rebirth of modality, which gradually brought considerable benefit to music. $9 \mathrm{He}$ put an end to the construction of thirds chord with a priori arrangement of material, as well as with modal scales, pentatonic and heptatonics. He instinctively aimed not only to synthesize sound material, but also to non-functionality. Changes in music have showed over time also by decrease of dependence on the modalities of sacral scales as far as so called "sequences "10were recognized as special parallel to modal thinking.

Modal use of tonal material in the release of improvisation rules can be seen within the composers of cool jazz on the turn of 50-ies and 60-ies in 20th century. Its pioneers were Gil Evans (1912-1988, pianist, composer, was influenced by composer Manuel de Falla), Miles Davis (jazz trumpetist, 1929-1991) and learning of pianist Leonard Joseph Tristan (19191978). ${ }^{11}$ Instead of complex harmonic structures priority was put to fewer chords in longer stretch, or one mode as a base for improvisation. The new simpler, modal tonal foundation allowed musicians to present more melodic than harmonic component. ${ }^{12}$ Theoretically this modal - improvisational concept was developed by composer and arranger Geoge Russell (1923) in work The Lydian Chromatic Concept of Tonal Organization (Brookline, Massachusetts, 1953). Among such musicians we can be classify pianist Bill Evans (1929-1980), as a master of music- improvisational colorfulness. Suggestions found itself in a cycle of preludes by C. Debussy (particularly in known Voiles).

Continuity to modality is also known in works of the Slovak musical composer Eugen Suchoň (1908 - 1993). His tonal structure of nine- tone- order (c-d-e flat-f-f sharp-g sharp-a-h-c), is presented as the most significant element of composer's music narration. Let us mention in such connection 0 . Messiaen, whose base of music narration is comprised from comprises seven models. When we compare his second mode in a second transposition, we find that it includes me the same tones as so called Suchon's scale. We can find it at the Dutch composer Henk Badings (1907-1987), as well as at the Austrian composer Theodor Berger (1905-1992). Book “Neue Harmonielehre”, 1927, A. Hába (1893-1973) reported over two hundred different scales among which Suchoň's tone order is placed. Its structure was even known by immemorial Arabic music.

It is interesting fact mentioning A. Skriabin (1872-1915), who is known for forming tone sequences for some of his compositions. This was consistently utilized the horizontal and vertical grade. For example from $C$ from sequence of higher overtones between 8 - 14 tones, i.e. from tones c2 - d2- e2- f sharp2- g2- a2- b2 he formed known synthetic quart chord - c - f sharp $-b-e-a-d-[g]$. Sometimes he left over 12th tone from stated tones $-\mathrm{g} 2$, (Chord is

\footnotetext{
${ }^{9}$ For more details see: JAROCIŇSKI, S.: Debussy. Impresionizmus a symbolizmus.[Debussy. Impressionism and Symbolism] Bratislava: Opus, 1989, 310 s. ISBN 80-7093-001-2.

${ }^{10} \mathrm{Group}$ of tones, characters that alternates according to certain rules.

${ }^{11}$ Since 1950 he had focused for music education; he is considered to be the first jazz teacher in a structured manner.

12Improvise on a single chord, or single mode to a larger spread was known manifestation creative. Different cultures used it for centuries. As well as clarinetist Benny Goodman in 1938 at his concert in Carnegie Hall, where he improvised the whole piece on a single chord.
} 
often denoted also as Prometheus or mystical chord)13. Search and creation of tone material at Skriabin had been associated with his efforts to associate music with visual and colorful impression.

Enrichment of Music narration thus could also be monitored in the eastern and central European cultures. They drawn partly from newly discovered modal harmonic a phenomenon, out of the rich modal effervescent of musical folklore, out of music of spontaneous creativity, as well as from taken elements of non-European cultures (so called artificially created "series"). "Currently we approach to herein modal phenomenon more or less ignoring conditioned origin connected to sacral modes, but to signs that at certain stages established characteristics of folklore, although collectors of such folk songs compared them in a simple manner with the features of ecclesiastical modes." 14 For many music composers of the 20th century, who gained in a new way from the music of spontaneous creativity, starting at a younger compositional period of I. Stravinsky (1882-1971), across the entire east, center of Europe to M. Falla (18761946), or B. Britten (1913-1976), it may be expressed as a productive, creative principle of group of characters creation aimed to be used in creative process.

Some composing schools, for example in the Czech Republic close to M. Ištvan (1978-1990), are seeing quality in perspective modality, which in the current production provides spontaneous music creativity, since providing rather varied options than traditional major minor type for music structure, tonal approach on one hand and atonal approach on the other.

In Western European cultural sphere (as already indicated), initially prevailed connection of modality with music-related procedures related to Messiaen's modes limited transpositions, as well understanding mode in terms of the procedures applied in dodecaphony, where out of organic structures of "sequence" melody, harmony, rhythm etc. is created. In regards to the development of musical patterns also in terms of modality we can state that importance of many procedures, techniques and trends applied in music of the $20^{\text {th }}$ century contributed to new opportunities to enrich melodic, harmonic and rhythmical component of musical language, as well as to reviving of the traditional composite processes.

Sincerely, herein phenomenon was acknowledged by Czech-Slovak musicology for decades. Since sixties of the last century scientists are increasingly concerned with not only the term "modality" but also analysis of music style of pieces by L. Janáček, B. Bartók, E. Suchoň and others. Modal features in Janáček's melody were identified by J. Vysloužil, ${ }^{15} \mathrm{~J}$. Volek, ${ }^{16} \mathrm{~J}$. Fukač with M. Štedrom. ${ }^{17}$ Among foreign musicologists it is necessary to mention at least G. Firc and S. Hellman.

\footnotetext{
${ }^{13}$ For more details also see Bartók's acoustic scale, or Messiaen chord resonating, composed of various overtone tones from 1-16 (c-e-g-b-d-f sharp-g sharp-h).

14FULKA,Vladimír. Modalita ako nová kvalita hudobnej kultúry 20. storočia. [Modality as a new quality of music culture of $20^{\text {th }}$ century]. In Hudba, Integrácie, interpretácie 16. Nitra , UKF Nitra, 2013, s.20. ISSN 1338-4872.

15 See: VYSLOUŽIL Jíŕí. Modální struktury u Janáčka. [Modal structures in Janáček]. In Hudební rozhledy. 19, 1966, č.18, s.552-555.

16 For more details see:VOLEK Jaroslav. Modalita a flexibilní diatonika u Janáčka a Bartóka. [Modality and flexible diatonics by Janacek and Bartok] In.: Československo - mad'arské vzt’ahy v hudbě. Ostrava: 1982, s. 68 - 95.

17 For more details see: FUKAČ Jiří - ŠTEDROŇ Miloš. Modalita, flexibilita a vývoj hudobného štrukturovania. [Mobility, flexibility and artist development structuring] Praha: 1983. In Zborník referátov z hudobno teoretického seminára. Zväz českých skladatel’ov a koncertných umelcov.1983, s. 47 - 69.
} 
MID-EUROPE18 - THE AREA WHERE CULTURES ARE MUTUALLY ENRICHED

Middle Europe's characteristic is that it was formed as multi- ethnic and polycultural region at small space. Close contact to another culture helped to develop not only own traditions, but also the feeling and ability to mutual communication, as well as the conditions for mutual influencing, taking over music elements into own creation process and own interpreting expression. Close neighborhood allowed exploring "live" folk music, as well as an artificial music of other nationalities or ethnicities. The breakthrough of folklore into artistic production in Central Europe was significant particularly at the turn of the $19^{\text {th }}$ and $20^{\text {th }}$ century. Expansion and integrating deepening of ethnic musical expressions in Central Europe happened under the influence of mutual contacts of the musicians (similarly, between Christian and Lutheran musicians). Music styles became integrating factor. One such attractive a music-style was called novouhorský (neougrian). It consisted of verbunková (music of recruits) music and so called novouhorská song. Its genesis is bound to kuruc song from the time of German Knights of the Cross dragging in Kingdom of Hungary. According to this fact, it is believed that it was not merely the product of Hungarian musical culture, since the creation platform was multiethnical. ${ }^{19}$

\section{ON BARTÓK'S CHORDS}

Of Hungarian composers B. Bartók contributed to new quality of musical culture the most. His works attracted attention of many musicologists that maybe related to composer's papers ${ }^{20}$ and perhaps with what we now call good management. In his texts he used terms like bimodal, polymodal as well as modal chromatics. The author's reflections obviously allowed better understanding of 12 tones within octave for music scientists. J. Karpáti, E. Lendvai, and a myriad of German scientists (e.g. C. Dahlhaus) can be involved to interesting scientist devoted to analyzing of musical language of B. Bartók.

As the most characteristic sign of Bartók's diatonics Lendvai considered acoustic scale $(c, d, e, f$ sharp, $g, a, b, c)$ consisting of overtones ( $8^{\text {th }}$ to $14^{\text {th }}$ tone from the base tone "c"). Acoustic chord „c-b -f sharp“ is derived from it, („,b" - minor seventh [c - b], ("f sharp“-augmented quart) [c- $f$ sharp]). No. 1

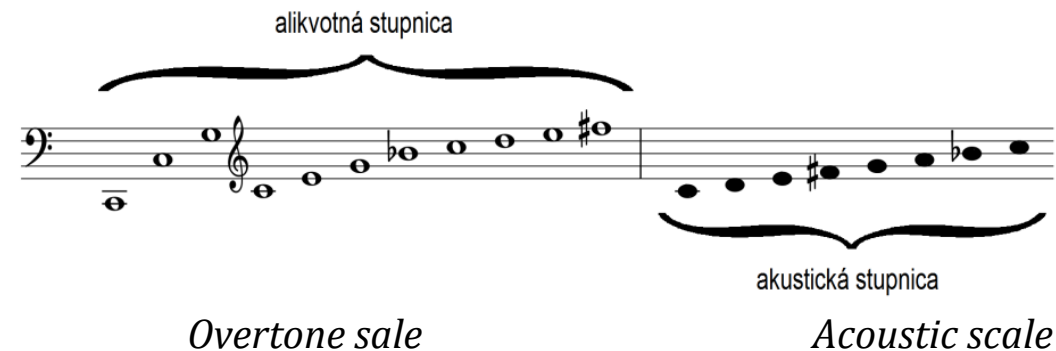

\footnotetext{
18 It is part of Europe between the eastern and western parts of Europe. Most often following countries are included Poland, Czech Republic, Hungary, Slovakia, Austria, Slovenia. Based on its culture and history they are often ranged to the West.

${ }^{19}$ Name Kuruc of latin origin „crux, cruciatus miles“ meaning cross, Knights of the Cross. Knights of the Cross at that time were Germans who dragged via Kingdom of Hungary down to Danube $(1096,1206)$. Later on, the name Kuruc in Kingdom of Hungary was also given to Tatars, Turks, as well as internal rebels, for example bočkayovci. Some kuruc songs originated from an old manuscript of Nitra chair in Prievidza (Kuruc song, Journey to Holy Ground). Among other things, they are also listed in the Song collection by Ján Kollár „Národnie spievanky 1." (National lullabies 1). Slovak composer Viliam Figuš - Bystrý edited kuruc songs and ballads for solo and choir with piano accompaniment.

${ }^{20}$ Bartók's most important works: A magyar népdal [Mad’arská l’udová pieseň [Hungarian folk song], Népzenénk és a szomszéd népek népzenéje Naša l'udová hudba a l'udová hudba susedných národov[Our folk music and folk music of neighboring nations], Miért és hogyan gyüjsünk népzenét? Prečo a ako zbierame l'udové piesne? [Why and how we collect folk songs].
} 
known as acoustic is developed at Bartók out of chords and colors of French impressionism that had inspiring influence on so called dualistic harmony thinking. Lendvai called Bartók's double harmony as "Bartók's chromatics" and „Bartók's diatonics “, known also as "System of golden mean " and "Acoustic system ". Its systematization was analyzed in detail by Lendvai21 especially by means of mentioned golden mean. In his process so called Fibonacci series of numbers plays an important role. Integers occurring in a row are the sum of the previous two figures: $1+1=2,1+2=3,2+3=5,3+5=8,5+8=13$ etc. Numbers of a row: $2,3,5,8,13,21$ etc. Number 2 indicates minor second, perfect third = minor third, perfect fifth, fourth etc., i.e. according to number of semitone steps. Irrational number of golden mean is obtained by dividing the closest numbers. For example $8: 13=0,615,13: 21=0,619$ and so on. Accumulating numbers form the characteristic intervals of golden section (we refer to as cells of size: $2,3,5,8,13),{ }^{22}$ and they are at the same time instruction to division of herein number, for example number 8 ratio $5+3$, or $3+5$.

No. 2

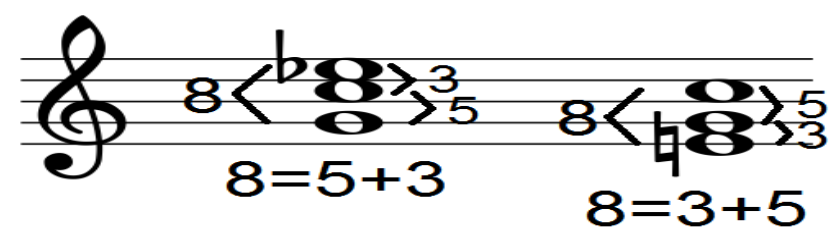

Construction of the aforementioned chord belongs to a feature of Bartók's chords within chromatics, where major third is entered by the composer under the base tone and minor third above the base tone "c" (g, c, e flat; e, g, c, i.e. c-e ).

By a chord combination in example No. 2 the most typical Bartók's chord is created which construction consists of minor third, perfect fourth and minor third (example No. 3). Chord's character is therefore major-minor and it is also filled with minor seventh $(b)$.

No.3

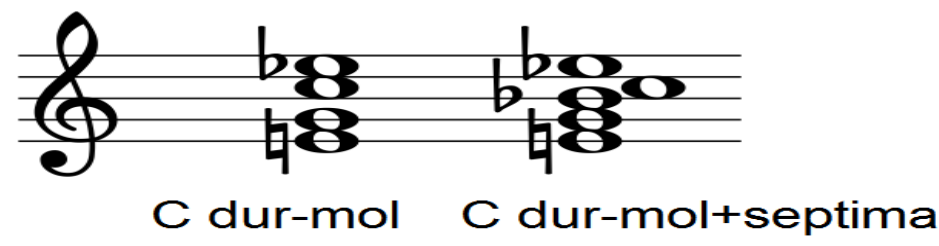
C major-minor
C major-minor+ seventh

Bartók is well known for sharing the opinion according to which folk music around the world comes from a few ancient origins. Obviously, therefore, in the construction of his most typical chords was based on the simple pentatonic scales motion, which is understood today (thanks to Lendvai) also as music "stylization "of golden mean. Comparing both systems, i.e. acoustic and golden mean systems, we find out that in the acoustic system there can be present major

21 LENDVAI, E.: Bartók dramaturgiája. Budapest: 1964. Zenemükiadó, 286 s.

22 Acoustic system favors following intervals in the harmony: fifth, major third and a natural sevenths. 
third instead of small third, instead of perfect fourth augmented fourth and instead of minor sixth major sixth. Following example shows that chromatics is somehow a reflection of acoustics that enables connection of both systems. That means that diatonic and chromatics are closely related, because chromatics is subject to the laws of the golden mean and diatonic is a faithful turnover of the golden mean system.

No. 4

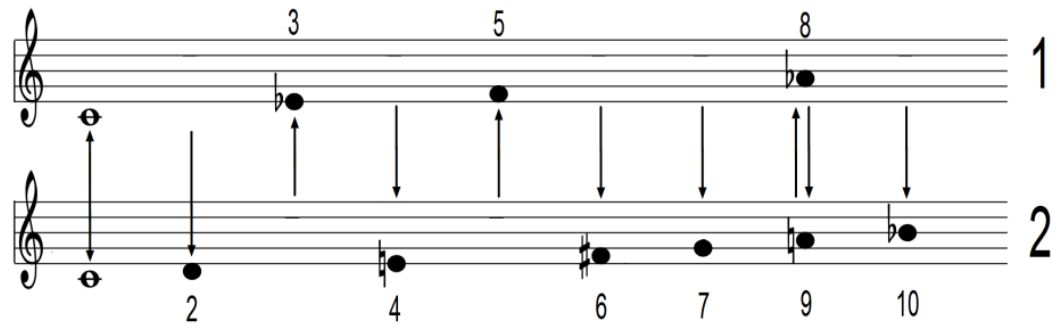

1 - golden mean scale

2 - acoustic scale 23

\section{SLOVAK MUSIC TRANSFORMATIONS}

In Slovak language area (in mixed linguistic environment, such as the Hungarian - Slovak), verbunková music continuously penetrated into folk environment (in the middle $19^{\text {th }}$ century from aristocratic- military district in the broader social layers in Kingdom of Hungary) by means of gipsy bands. Their musical performance was very compelling, vivid. They proved a charming lightness to adapt to contemporary taste, social layers, social situation as well as the particular requirements of visitors, guests at the public events. Urban (Gipsy) bands could include into their repertoire impulses coming from Western European environment (Viennese classicism, waltzes, operettas by J. Strauss, etc.), but also domestically music pieces as well (operettas by Miloslav Francisci, Gejza Dusík, etc.), which corresponded with European music trends so called music for "listening"24

Within national emancipatory efforts in 19th century in Slovak surrounding there was strong departure from neo-ugrian style, since interest in creating Slovak national music increased. Music creators focused more on shepherd folklore of mountain areas (which used musical instruments like fujara (shepherd's overtone fipple flute), bagpipes, etc.). At that time the world-renowned authors such as Bartók and Kodály began to consider Hungarian rural folk music for more authentic, a source of domestic traditions. Orientation for authentic folklore did not prevent many composers from seeking inspiration in gipsy production aimed to be implemented into their composition. For example Franz Schmidt, Franz Liszt, Johann Brahms, Maurice Ravel, Antonín Dvořak and many other renowned composers. Of Slovak composers let's mention Dezider Lauko, Zdenko Mikula.

For Slovak composers B. Bartók was inspiring personality as originated from the neighboring country. Slovak area was not that much inspired by new streams in the first decade of 20th

\footnotetext{
${ }^{23}$ Similar explanation is found in a study of BOKES, Vladimír. Princíp zlatého rezu v hudobnej kompozícii. [The principle of the golden mean in music composition] In Slovenská hudba, r.24, č.1 - 2, s. 59 - 64.

${ }^{24}$ Music for listening (table) was performed in cafes, e.g. at the dinner or different occasions.
} 
century due to illegible conditions we are not able to explain. ${ }^{25}$ Some of the reasons for late binding to compositions of B. Bartók are especially dependence of Slovak music on impressionism (although it did not appear in pure form, but with neo-classicist elements, for example A. Moyzes, 1906 - 1984).

Similar reasons are noted for innovative music thinking of Igor Stravinsky, (1882 - 1971), in particular his impact of "Russian period" for the formation of Prokofiev (1891-1953), Shostakovich (1906-1975), Bartók, Szymanowski (1882-1937). Stravinsky had inspired music composers of neighboring nations by creative application of the expressive elements taken from folk fundamental prerequisite, rhythmic riches, new techniques of instrumentation etc. At this time various cultural elements were present on the Slovak territory; this trend was likely to cause a dilemma with addressing Slovak man in the work of young creators. Another issue was dealing with poor Slovak music tradition, since Austro - Hungarian Empire monarchy fell apart in the year 1918 (after the end of World War I), that " delayed: relation and interest about new music presentation. Bartók's suggestions were creatively applied only by Dezider Kardoš (1914 - 1991) in the harmonic - melodic expression. Stronger links in the Slovak composers show up on Szymanowski, and especially at J. Cikker (1911 - 1989). After 1918 (the creation of the Czechoslovak state after the collapse of Kingdom of Hungary) Slovaks were inspired by Czech composer Vítězslav Novák (1870-1949).

\section{MAIN FEATURES OF COMPOSITIONAL STYLE OF EUGEN SUCHOŇ}

Cessation of multiethnic state form allowed exceeding existing state of Slovak musical culture. Establishment of a new state (Czechoslovakia) has opened the way to new artistic ambitions of Slovak composers, in which roots of origins were not questioned. For example Eugen Suchoň is known not to grow up among live tradition of Slovak folklore. He got to know Slovak folklore thanks to his teacher at Music and Drama Academy for Slovakia in Bratislava26 F. Kafendom (1883- 1963) as well as knowing composite directions. Another impulse for his personal artistic style was study of composition at the listed V. Novák27 in Prague (1931-1933), where he could be inspired by beneficial symbiosis between Czech and German cultural activities. His compositional concept was profiled on finding the contact points between the traditional harmonic tonality and free modality based on 12-tone-principle. Rationally taken twelve-tone modality Suchoň created the modern theoretical - artistic context with the current domestic context, which artistically motivated to creative work onset Slovak generation of composers (Juraj Beneš, Roman Berger, Jozef Malovec, Ilja Zelienka etc.). Some kind of music language development summary, particularly taken educational point of view, can be followed in Suchoň's theoretical work Akordika [Acordics] (1979) ${ }^{28}$, where musical thinking and pedagogical intentions were approached (between 1941-1960 taught at the Conservatory in Bratislava and between 1963-1974 he lectured at Comenius University in Bratislava). Within music pieces of instructive character we can follow development of music language in piano cycle Obrázky so Slovenska [Pictures from Slovakia]. It is created of 22 pieces of music arranged

\footnotetext{
${ }^{25}$ Bartók Béla was anti-fascist, he immigrated to USA. He collected folk song since 1904. The ethno musicological works have outlined typology of Hungarian folk music and comparison with the folk music of neighboring nations. 26 Sicne 1941 school is called State Conservatory in Bratislava.

27 In particular, therefore, as V. Novák had direct composing connection to Slovak songs, while works of L. Janáček was almost not implemented in 30-ies and 40-ies of the last century (only partially at A. Očenáš, which was reflected in its polymelodic and motet compositional structure.

${ }^{28} \mathrm{He}$ read lectures about Acordics also at University of Michigan, after the premiere of the opera Krútňava in 1979 in Lansing (state Michigan).
} 
into six cycles. ${ }^{29}$ The composer worked gradually from the smallest to the most demanding pieces. Student is led from the simplest harmony links to more complicated harmonic narration.

"Sonata rustica "is the last piece of above listed cycle. He utilized mode in the range of fifths to hexachord, where author pointed out on the one hand the riches contained in the Slovak folk songs (freely used chromatics was used as well as parts growing from structure of well known tonal row). On the other hand he "visualized" his musical thinking the way to include modern harmony into the modes contained in Slovak songs melody. Thus he disproved opinions of many older Slovak composers (may accidentally), who even after many years after stylistic direction of Bartók and Kodaly stated that many Slovak songs could not be harmonized majorminor system (obviously related to the fact that Slovak composers used especially Lydian mode).

\section{CONCLUSION}

Sonata rustica was preferred from the cycle because Eugen Suchoň applied didactic intent in it. It provides compelling evidence that the Slovak folk melody is inspiring base for a modern music production, harmony, especially if growing from its tonal material. It is also appropriate educational material, not only just for piano students, but also for anyone who is interested in modality, Slovak folk songs and finding incentives from the Slovak melody for own work.

\section{BIBLIOGRAPHY}

BOKES, Vladimíra. 1998. Princíp zlatého rezu v hudobnej kompozícii [The Principe of the Golden Mean in Musical Composition]. In Slovenská hudba. ISSN 1335-2458, 1998, roč. 24, č.1 - 2, s. 59 - 64.

ELSCHEK, OSKAR. 1959. Pojem a základné znaky hudobného folklóru [Concept and main features of folklore music]. In: Hudobnovedné štúdie III. Bratislava: SAV, 1959, s. 5-42.

FUKAČ, Jiří - ŠTEDROŃ, Miloš. 1983. Modalita, flexibilita a vývoj hudobného štrukturovania [Modality, flexibility and development of musical structuring]. In Živá hudba VIII. Praha: Zväz českých skladatel'ov a koncertných umelcov, 1983, s. $47-69$.

HÁBA, Alois. 1937. Harmonické základy dvanáctitónového systému [Basics to harmony of twelve-tone system]. In Tempo. 1937, roč. 17, č. 12, s. 128-130.

HRČKOVÁ, Nad'a. 1998. Eugen Suchoň a teória jedinej cesty. Pocta Eugenovi Suchoňovi [Eugen Suchoň and his single way theory. Tribute to Eugen Suchoň]. In Eugen Suchoň v kontexte európskej hudby 20. storočia. Bratislava: NHC,1998, s.43-49.

CHALUPKA L’ubomír.2000. Konvergencie II. pre violu od Romana Bergera - analytické poznámky [Convergence No. II for viola from Roman Berger - analytical notes]. In Hudobno - pedagogické interpretácie 5 (edit. J. Vereš). Nitra: RZ SHÚ, . ISBN 80-8050-351-6, 2000, s. 32 - 39

CHALUPKA Lubomír. 1998. Eugen Suchoň a 12 tónov v oktáve [Eugen Suchoň and 12 tones in the octave]. In Slovenská hudba. Revue pre hudobnú kultúru. ISSN 1335-2458,1998, roč. 24, č. 1-2, s. 5- 35.

JAROCIŃSKI, Stefan. 1989. Debussy. Impresionizmus a symbolizmus [Debussy. Impressionism and symbolism]. Bratislava: Opus,1989, 310 s.ISBN 80-7093-001-2.

KRESÁNEK, Jozef. 1997. Slovenská l'udová pieseň zo stanoviska hudobného [Slovak folk song from the musical point of view]. Bratislava: Národné hudobné centrum, 1997, 308 s.

LENDVAI, Ernö. 1964. Bartók dramaturgiája [Bartók dramaturgy]. Budapest: Zenemükiadó, 1964, 285 s.

MARTINÁKOVÁ, Zuzana. 1998. Úvahy o možnostiach organizácie tónov na pozadí Suchoňovho systému akordiky [Reflections on tonal organization options based on Eugen Suchoň's chord-system]. In Slovenská hudba. ISSN 1335-2458, 1998,roč. 24, č. 1 - 2, 1998, s. 36 - 46.

${ }^{29}$ 1. Maličká som, 2. Ked’ sa vlci zišli, 3. Preletel sokol, 4. Sonatína, 5. Horalská suita, 6. Sonata rustica. 
MLODZIEJOWSKI, Jerzy.1957. Szymanowského gorálsky balet Harnasie [Goral ballet Harnasie by Szymanowski]. In Slovenská hudba. 1957, roč. 1 č. 8-9, s.263 -265.

RISINGER, Karel. 1961. Otázka nových tónových systémů [Questions of new tonal systems]. In Hudební věda. 1961, č. 1, s.74-94.

SUCHOŇ, Eugen. 1979. Akordika: od trojzvuku po dvanást'zvuk [Acordics: from three-tone to twelve-tone chords]. Bratislava: Opus. 1979, 171 s.

TICHÝ, Vladimír. 1983. Modalita. (Systematika) [Modality. (Systematics)]. In Živá hudba VIII. Praha: Zväz českých skladatel'ov a koncertných umelcov,1983, s.117 - 191.

URBANCOVÁ, Hana. 1998. „Uhorské“prvky v hudobnej tvorbe Franza Schmidta [“Ugrian“ elements in the works of Franz Schmidt]. In Slovenská hudba. ISSN 1335-2458. 1998, roč. 24, č. 3, s. 388 - 409.

VEREŠ, Jozef. 2015. Metamorphosis Music. In International Journal of Music and Performing Arts. 2015, vol. 3,No 1, pp. 96-102 .ISSN 2374-2690.

VEREŠ, Jozef - MAJERNÍK Vladimír.1980. Hudobná teória [Music Theory]. (Zod. red. Zorka Nünzová). Bratislava: SPN, 1980, $144 \mathrm{~s}$.

VEREŠ Jozef. 2008. Modalita ako flexibilný fenomén v hudbe 20. storočia [Phenomenon of modality and flexibility in 20th century music ]. In Opus musicum. ISSN 0862-8505, 2008, roč. č.1, s. 13 - 17.

VEREŠ, Jozef. 2011. Hudobné korelácie [Musical correlations].In Hudba, Integrácie, Interpretácie 14. Nitra, Univerzita Konštantína Filozofa v Nitre, 2011, 233 s.ISBN 978-80-558-0003-5, ISSN 1338-4872.

VOLEK, Jaroslav. 1982. Modalita a flexibilní diatonika u Janáčka a Bartóka. [Modality and flexible diatonics in works of Janaček and Bartok]. In Československo - mad'arské vzt'ahy v hudbě.Ostrava: Krajské kulturní středisko Ostrava, 1982, s. 68-95.

VYSLOUŽIL, Jíŕí. 1966. Modální struktury u Janáčka. [Modal structures in works of Janaček]. In Hudební rozledy. 19,1966, č.18, s.552-555.

ŽABKA, Marek. 2000. Kompozičná technika v diele Romana Bergera Konvergence I. [Techniques of compositions in Konvergencie I. by Roman Berger]. In Hudobno - pedagogické interpretácie 5 (edit. J. Vereš). Nitra: RZ SHÚ, 2000, s. 26 - 31. ISBN 80-8050-351-6. 